\title{
FABRICATION OF THE P-N JUNCTION ULTRAVIOLET PHOTODETECTORS BASED ON METAL OXIDE NANOPARTICLES
}

\author{
İsmail Cihan KAYA \\ Konya Technical University, Faculty of Engineering and Natural Sciences, Department of Metallurgical \& \\ Materials Engineering Konya, TÜRKIYE \\ ickaya@ktun.edu.tr
}

(Geliş/Received: 13.01.2022; Kabul/Accepted in Revised Form: 17.02.2022)

\begin{abstract}
Recently, wide bandgap metal oxides have attracted tremendous attention in the field of UV photodetectors due to their promising optoelectronic properties. Up to now, various approaches have been used to design metal oxide-based UV photodetectors. Among these designs, p-n junction UV photodetectors exhibited remarkable performance. In this study, $\mathrm{TiO}_{2} / \mathrm{CuCrO}_{2}$ p-n junction as a UV photodetector was fabricated with spin coating method for the first time. The morphological and optical properties of the fabricated devices were investigated in detail. Moreover, the effect of the $\mathrm{CuCrO}_{2}$ thickness on the performance of the UV photodetector was explored. The fabricated devices showed promising diode behavior and UV response. The responsivity $(R)$ and specific detectivity $\left(D^{*}\right)$ of the best device were $3.11 \mathrm{~mA} / \mathrm{W}$ and $2.37 \times 10^{11}$ Jones, respectively at $-1.5 \mathrm{~V}$ under $3 \mathrm{~mW} / \mathrm{cm}^{2}$ light intensity.
\end{abstract}

Keywords: UV photodetector, Metal oxide nanoparticles, $P-N$ heterojunction, Thin film

\section{Metal Oksit Nanopartikül Esaslı P-N Eklem UV Fotodedektörlerin Üretimi}

ÖZ: Son zamanlarda, geniş bant aralığı değerine sahip metal oksitler umut vaat eden optoelektronik özelliklerinden dolayı UV fotodedektör uygulamalarında ilgi görmektedir. Bugüne kadar yapılan çalışmalarda, farklı yaklaşımlar kullanılarak metal oksit esaslı UV fotodedektörler geliştirilmeye çalışılmıştır. Bunlar içerisinde, p-n eklem UV fotodedektörler gösterdikleri performans ile dikkat çekmiştir. Bu çalışmada, döndürmeli kaplama yöntemi kullanılarak ilk defa $\mathrm{TiO}_{2} / \mathrm{CuCrO}_{2}$ p-n eklem UV fotodedektörler üretilmiştir. Üretilen malzemelerin morfolojik ve optik özellikleri detaylı bir şekilde analiz edilmiştir. Buna ek olarak, $\mathrm{CuCrO}_{2}$ film kalınlığının UV fotodedektör performansına etkisi incelenmiştir. Üretilen p-n eklemlerin umut vaat eden diyot davranış sergilediği ve UV ışığa karşı duyarlı olduğu gözlemlenmiştir. En iyi performans gösteren dedektörün, $1,5 \mathrm{~V}$ gerilim ve $3 \mathrm{~mW} / \mathrm{cm}^{2} 1$ şık şiddeti altında duyarlılık değeri 3,11 mA/W ve spesifik dedektivite $\left(D^{*}\right)$ değeri ise 2,37x1011 Jones olarak bulunmuştur.

Anahtar Kelimeler: UV fotodedektör, Metal oksit nanopartiküller, P-N hetero-eklem, Ince film

\section{INTRODUCTION}

The Ultraviolet (UV) photodetectors, which convert the UV light energy into electric signals, find many applications such as light-wave communications, flame detection, ozone monitoring, and missile detection (Zou et al., 2018) . Traditionally, a photomultiplier tube (PMT) and silicon have been used as UV photodetectors; however, high voltage and vacuum environment requirement of PMTs and the necessity of using optical filters to block visible and infrared part of the electromagnetic spectrum for silicon-based UV photodetectors have created the need for the development of new UV photodetector materials (Xie et 
al., 2019). Due to their wide bandgap, metal oxides such as $\mathrm{Ga}_{2} \mathrm{O}_{3}, \mathrm{ZnO}, \mathrm{SnO}_{2}$, and $\mathrm{TiO}_{2}$ have attracted considerable attention as alternative materials for UV photodetectors (Deka Boruah, 2019; Wu and Kuo, 2009; $\mathrm{Xu}$ et al., 2019; Yadav et al., 2022). Among these materials, $\mathrm{TiO}_{2}$ is one of the most extensively researched n-type semiconductor materials due to its radiation hardness, thermal and chemical stability, easy and low-cost fabrication, and promising optical and electrical properties (Noman et al., 2019). Up to now, various device designs have been developed to fabricate efficient $\mathrm{TiO}_{2}$ based photodetectors (Huang et al., 2011; Karaagac et al., 2012; Li et al., 2012; Nicolaescu et al., 2021). Fabricating the heterojunction device with $\mathrm{TiO}_{2}$ and p-type semiconductor is one of the effective techniques for enhancing the photogenerated charge separation efficiency, which improves the photodetector performance (Yang et al., 2021). Moreover, an inner electric field is created at the interface with the formation of the $p$ - $n$ heterojunction. Therefore, the photogenerated electron-hole pairs in the depletion regions are separated without an external power supply (Gao et al., 2018).

Many organic and inorganic p-type semiconductors have been applied as a p-type counterpart to fabricate $\mathrm{TiO}_{2}$ based p-n junction UV photodetectors (Nicolaescu et al., 2021; Wang et al., 2015; Zheng et al., 2016). Due to the stability concern of organic semiconductors, inorganic p-type semiconductors, mainly metal oxides, come to the fore in p-n junction UV photodetectors. However, the poor conductivity of the p-type metal oxide semiconductors generally inhibits the efficient transport of the photogenerated carriers. Therefore, extensive research efforts have been put into developing the new p-type metal oxides.

The copper-based delafossite oxides $\left(\mathrm{CuMO}_{2}, \mathrm{M}: \mathrm{Al}, \mathrm{Cr}\right.$, $\mathrm{Ga}$, etc.) are promising p-type semiconductors with a wide bandgap (Zhang et al., 2019). Among these materials, $\mathrm{CuCrO}_{2}(E g \sim 3.1 \mathrm{eV})$ has shown the best optoelectronic properties and has been used in various areas such as transparent conducting oxides, transparent diodes, photocatalysis, gas sensors, and solar cells (Bai et al., 2021; Dursun et al., 2018; Kaya et al., 2018; Tonooka and Kikuchi, 2006; Zhou et al., 2009). There are also a few recently reported studies where $\mathrm{CuCrO}_{2}$ has been used to fabricate $\mathrm{p}-\mathrm{n}$ junction photodetectors such as $\mathrm{ZnO} / \mathrm{CuCrO}_{2}$, Al-doped $\mathrm{ZnO} / \mathrm{Mg}$, and $\mathrm{N}$-doped $\mathrm{CuCrO}_{2}$, and $\mathrm{Ga}_{2} \mathrm{O}_{3} / \mathrm{CuCrO}_{2}$ (Ahmadi et al., 2021; Cossuet et al., 2018; Wu et al., 2021). All the photodetectors fabricated based on the $\mathrm{CuCrO}_{2}$ showed significant diode behavior and high UV responsivity.

$\mathrm{CuCrO}_{2}$ can also be considered potential p-type semiconductors for $\mathrm{TiO}_{2}$ based p-n junction UV photodetectors due to their high p-type conductivity, wide bandgap, and type-II alignment with $\mathrm{TiO}_{2}$. In this study, $\mathrm{TiO}_{2} / \mathrm{CuCrO}_{2}$ heterojunction films as a UV photodetector were fabricated using a simple solution-based method for the first time. The optical and morphological properties of the films and UV photodetector performances of the devices were studied.

\section{MATERIALS AND METHOD}

\subsection{Fabrication of The P-N Heterojunction UV Photodetectors}

In order to fabricate $\mathrm{p}-\mathrm{n}$ heterojunction, $\mathrm{TiO}_{2}$ and $\mathrm{CuCrO}_{2}$ films were deposited on the fluorine-doped tin oxide (FTO) coated glass substrate by a spin coating method. FTO substrates were cleaned in an ultrasonic bath using de-ionized water, acetone, and ethanol for 15 minutes before the film deposition. After cleaning the substrates, diluted $\mathrm{TiO}_{2}$ paste (30NRD, Dyesol, TiO2/ethanol:1/6, w/w) was coated on the FTO layer at $4000 \mathrm{rpm}$ for $20 \mathrm{~s}$ using spin coating and annealed at $450{ }^{\circ} \mathrm{C}$ for $30 \mathrm{~min}$ in air. Hydrothermally synthesized $\mathrm{CuCrO}_{2}$ nanoparticles were used as a p-type counterpart of the p-n junction. Synthesized procedure and properties of the $\mathrm{CuCrO}_{2}$ nanoparticles were explained in our previous studies in detail (Kaya et al., 2016). In order to form $\mathrm{CuCrO}_{2}$ film on the $\mathrm{TiO}_{2}$ layer, $5 \mathrm{mg} / \mathrm{mL} \mathrm{CuCrO} 2$ dispersion in isopropanol was spin-coated at $3000 \mathrm{rpm}$ for $30 \mathrm{~s}$ and was annealed at $300{ }^{\circ} \mathrm{C}$ for one h. $\mathrm{CuCrO}_{2}$ films with different thicknesses were produced to investigate the effect of the p-type layer thicknesses on the photodetector performance. $\mathrm{CuCrO}_{2}$ thickness was adjusted by changing the number of the coatings layers (10 and 20 layers). Finally, a copper tape foil $(4 \times 4 \mathrm{~mm})$ was used as an electrode on top of the p-n heterojunction. 


\subsection{Characterization}

The transmittance spectra of the films were recorded between 300-800 $\mathrm{nm}$ using Shimadzu UV-2600 UV-Vis spectrophotometer. The microstructural features of the films were investigated using SM Zeiss LS-10 scanning electron microscope (SEM). The current density-voltage (J-V) curves of devices were recorded by Gamry Interface 1010B Potentiostat/Galvanostat. A 365 nm UV LED (Cree LED, 3W) was used as a light source. The power density of the incident light was adjusted by changing the distance between the UV LED and the sample. The illumination power was measured using a Newport 842-PE power meter equipped with a Newport $818 \mathrm{P}$ power detector.

\section{RESULTS AND DISCUSSION}

The morphological properties of both $\mathrm{TiO}_{2}$ and $\mathrm{CuCrO}_{2}$ films were examined by SEM analysis. SEM images of the $\mathrm{TiO}_{2}$ film on the FTO layer, 10 layers of $\mathrm{CuCrO}_{2}$ film, and 20 layers of $\mathrm{CuCrO}_{2}$ film on the $\mathrm{TiO}_{2}$ layer are presented in Figure 1 (a), (b), and (c), respectively. As can be seen from Figure 1(a), continuous $\mathrm{TiO}_{2}$ nanoparticulate film deposited the whole FTO surface uniformly. Although the $\mathrm{CuCrO}_{2}$ nanoparticles seemed to be largely deposited individually throughout the film, some $\mathrm{CuCrO}_{2}$ nanoparticles agglomerated and were not distributed (Figure 1(b) and (c)). Moreover, small pinholes were observed on the surface of the $\mathrm{CuCrO}_{2}$ films. The formation of the pinholes is a sign of poor coverage of the $\mathrm{TiO}_{2}$ film surface, which can result in direct contact between the $\mathrm{TiO}_{2}$ layer and the metal electrode.
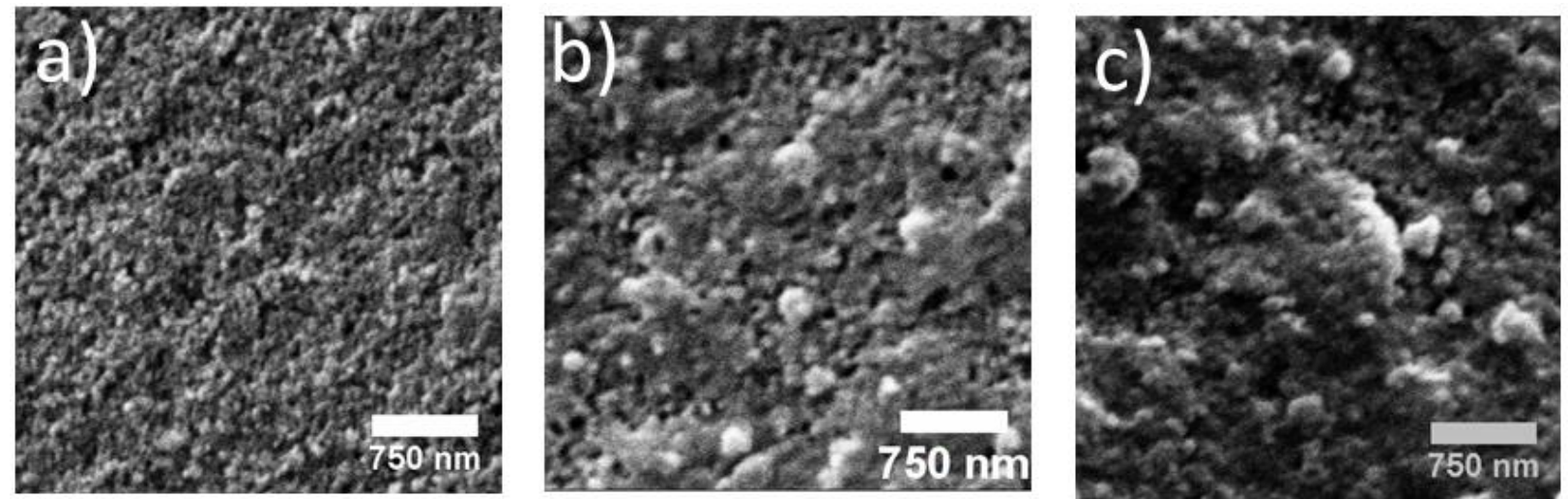

Figure 1. SEM images of the (a) $\mathrm{TiO}_{2}$, (b) 10 layers of $\mathrm{CuCrO}_{2}$ film, and (c) 20 layers of $\mathrm{CuCrO}_{2}$ film (The SEM images were captured at $100 \mathrm{kx}$ magnification)

The optical properties of the $\mathrm{TiO}_{2}$ film and $\mathrm{TiO}_{2} / \mathrm{CuCrO}_{2}$ p-n junctions were investigated by measuring the absorbance and transmittance spectra in the wavelength range $300-800 \mathrm{~nm}$ with a UV-VIS spectrophotometer. The transmittance and absorbance spectra of the $\mathrm{FTO}, \mathrm{FTO} / \mathrm{TiO}_{2}, \mathrm{FTO} / \mathrm{TiO}_{2} / 10$ layers $\mathrm{CuCrO}_{2}$, and $\mathrm{FTO} / \mathrm{TiO}_{2} / 20$ layers $\mathrm{CuCrO}_{2}$ are given in Figure 2 (a) and (b), respectively. The transmittance value of the FTO substrate was $\sim 80 \%$ in the visible range $(400-700 \mathrm{~nm})$ of the electromagnetic spectrum. It is important to note that the $\mathrm{TiO}_{2}$ film slightly improved the optical transmittance of the FTO layer between the 380 and $500 \mathrm{~nm}$ wavelength. It can be attributed to the formation of the smoother surface when the FTO layer is covered with $\mathrm{TiO}_{2}$ film. On the other hand, deposition of the 10 layers of $\mathrm{CuCrO}_{2}$ film on the $\mathrm{TiO}_{2}$ layer surface decreased the transmittance of the device. The transmittance value of the $p$-n junction fabricated with 10 layers of $\mathrm{CuCrO}_{2}$ was $\sim 40 \%$. Therefore, the p-n junction with 10 layers of $\mathrm{CuCrO}_{2}$ can be called a semi-transparent device. However, further increasing the thickness of the $\mathrm{CuCrO}_{2}$ layer $(20$ layers) led to a decrease in transmittance value to $20 \%$ in the visible range, which can be explained by a high light-scattering due to the porous and rough film (Ko et al., 2012). In addition, the absorbance spectra are shown in Figure 2(b) revealed that all the samples exhibited strong absorption in the UV region. However, the absorption edges of the samples were different from each other. The absorption edge of the FTO, FTO/TiO $2, \mathrm{FTO} / \mathrm{TiO}_{2} / 10$ layers $\mathrm{CuCrO}_{2}$, and $\mathrm{FTO} / \mathrm{TiO}_{2} / 20$ layers $\mathrm{CuCrO}_{2}$ were found to be $325 \mathrm{~nm}$, 
$335 \mathrm{~nm}, 351 \mathrm{~nm}$, and $402 \mathrm{~nm}$, respectively. Therefore, the devices fabricated with 20 layers of $\mathrm{CuCrO}_{2}$ would absorb all the UV-A regions.
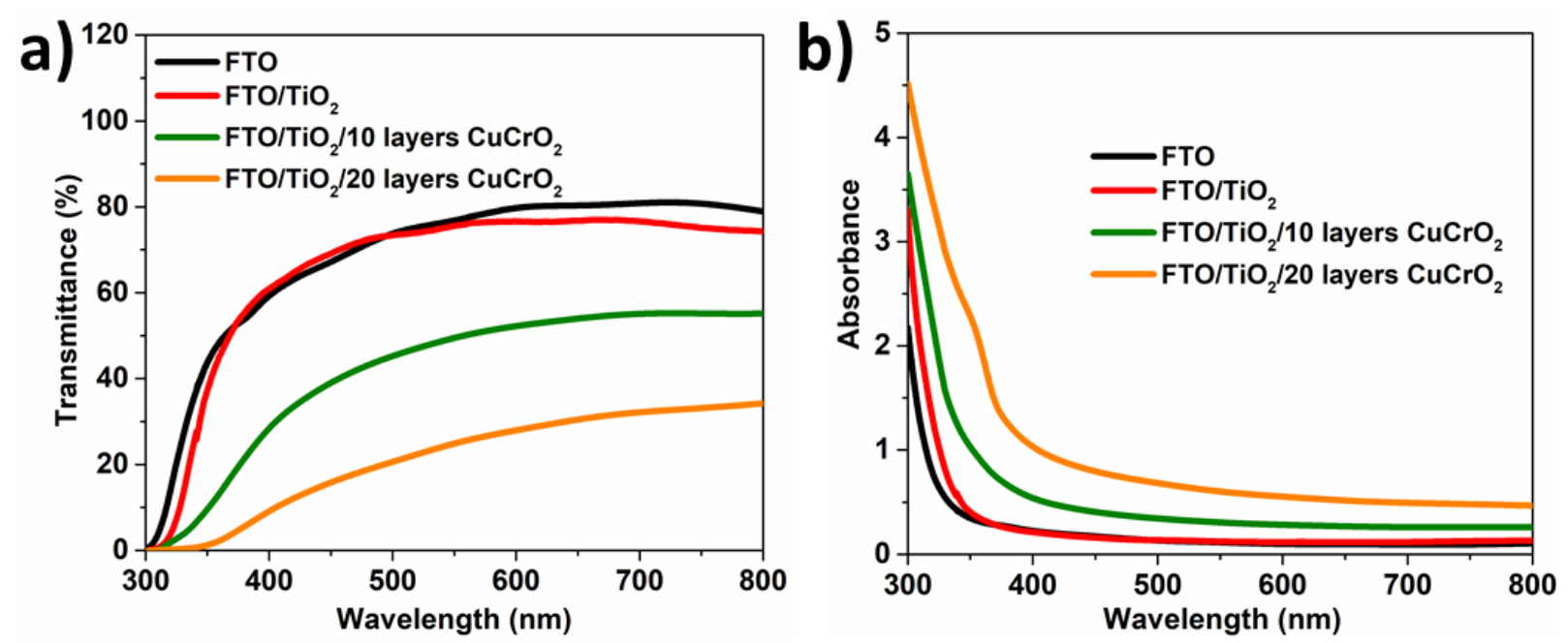

Figure 2. (a) The transmittance and (b) the absorbance spectra of the samples

The device configuration for the p-n heterojunction photodetectors fabricated in this study was $\mathrm{FTO} / \mathrm{TiO}_{2} / \mathrm{CuCrO}_{2} / \mathrm{Cu}$, as shown in a schematic illustration in Figure 3(a). While the thickness of the $\mathrm{TiO}_{2}$ was held constant, two different thicknesses of $\mathrm{CuCrO}_{2}$ were coated by adjusting the number of coating layers (10 and 20 layers). Thus, the effect of the $\mathrm{CuCrO}_{2}$ thickness on the photodetector performance of the p-n heterojunction was explored. All the photodetectors were illuminated through the glass substrate side during the current-voltage (I-V) measurements. The dark and $365 \mathrm{~nm}$ UV light illuminated J-V curves of the p-n heterojunctions fabricated with $\mathrm{CuCrO}_{2}$ with 10 and 20 layers are given in Figure 3(b) and (c), respectively. In dark conditions, the current density under reverse bias was lower than that of the under forward bias for all the devices, resulting in non-linear J-V curves. This situation suggests that all the fabricated devices behave like rectifiers which proves the formation of a $p-n$ junction diode. The Jforward/Jreverse ratios (rectification ratio) at $1.5 \mathrm{~V}$ were 1.57 and 13.54 for the $\mathrm{TiO}_{2} / \mathrm{CuCrO}_{2} \mathrm{p}$-n junctions fabricated with 10 and 20 layers of $\mathrm{CuCrO}_{2}$, respectively. The low rectification ratio of the device fabricated with thin $\mathrm{CuCrO}_{2}$ (10 layers) can be attributed to the poor surface coverage of the $\mathrm{CuCrO}_{2}$ film on the $\mathrm{TiO}_{2}$ surface. As can be seen in the figures, at both reverse and forward bias voltages, the current density of the devices increased under the $365 \mathrm{~nm}$ UV light illumination. Moreover, the photocurrent value of both devices increased with increasing light intensity, which showed that the devices are photosensitive to UV light with $365 \mathrm{~nm}$ wavelength and generate the photocurrent. It is worth noting that although the formation of the p-n junction, the current density of the devices was almost zero under UV illumination in zero bias voltage. It can be due to the high defect density at $\mathrm{TiO}_{2} / \mathrm{CuCrO}_{2}$ heterojunction interface due to the void formation between nanoparticulate-based films. Therefore, the photogenerated carriers can not be transferred without a bias voltage. 
a)

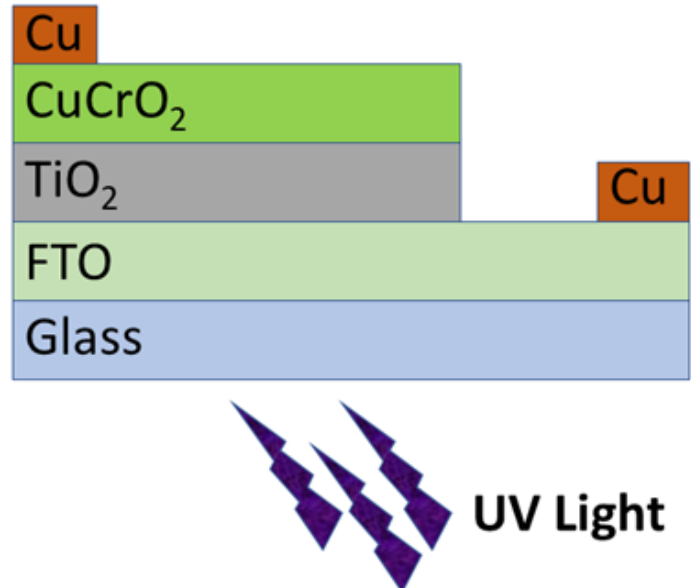

b)

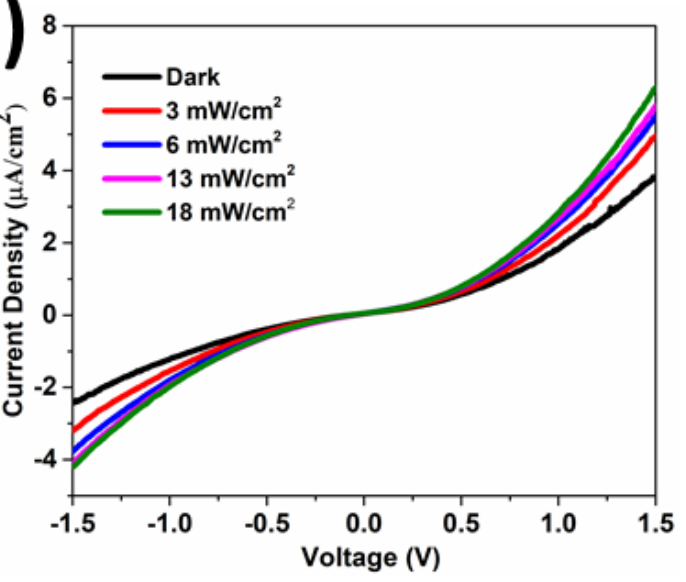

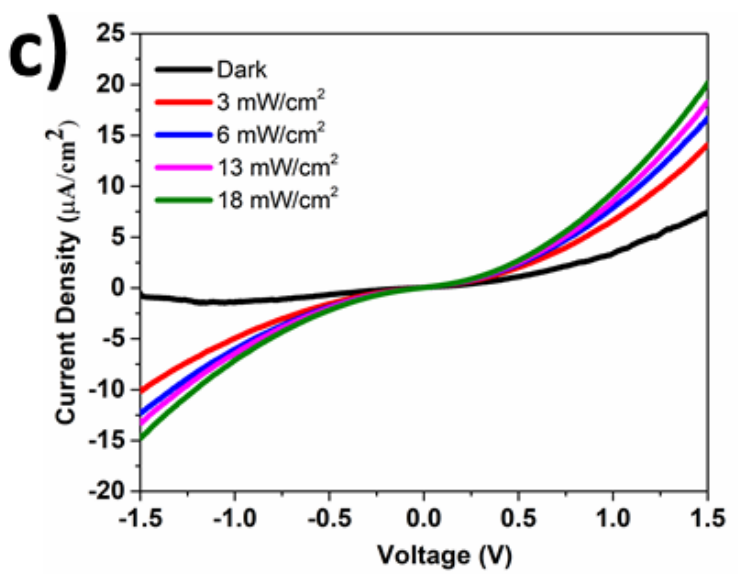

Figure 3. (a) Schematic illustration of the $\mathrm{FTO} / \mathrm{TiO}_{2} / \mathrm{CuCrO} / \mathrm{Cu}$ photodetectors, the $\mathrm{J}-\mathrm{V}$ curves of the photodetectors fabricated with (b) 10 layers and (c) 20 layers of $\mathrm{CuCrO}_{2}$ film

The responsivity can be defined as the photogenerated current per unit incident light power (Deka Boruah, 2019). Therefore, it is one of the critical parameters to determine the performance of the photodetector. The responsivity values of the detectors were calculated according to the following equation:

$$
R=\frac{J_{\text {light }}-J_{\text {dark }}}{P_{i}}
$$

Where $\mathrm{R}$ is the responsivity and $\mathrm{P}_{\mathrm{i}}$ is the incident light power. The responsivity values of the $\mathrm{p}-\mathrm{n}$ heterojunctions fabricated with 10 and 20 layers of $\mathrm{CuCrO}_{2}$ are shown in Fig 4(a) and 4(b), respectively. As can be seen in the figures, the responsivity values of the detectors were calculated at -1 and $-1.5 \mathrm{~V}$ under four different UV power densities at $365 \mathrm{~nm}$ to investigate the effect of applied bias voltage and the light intensity. The responsivity value of the detector with 10 layers of $\mathrm{CuCrO}_{2}$ was $0.10 \mathrm{~mA} / \mathrm{W}$ at $-1 \mathrm{~V}$ under 3 $\mathrm{mW} / \mathrm{cm}^{2}$ light intensity and enhanced to $0.25 \mathrm{~mA} / \mathrm{W}$ with increasing voltage $(-1.5 \mathrm{~V})$ due to the effective separation of the electron-hole pairs with a driving force of the bias voltage. 

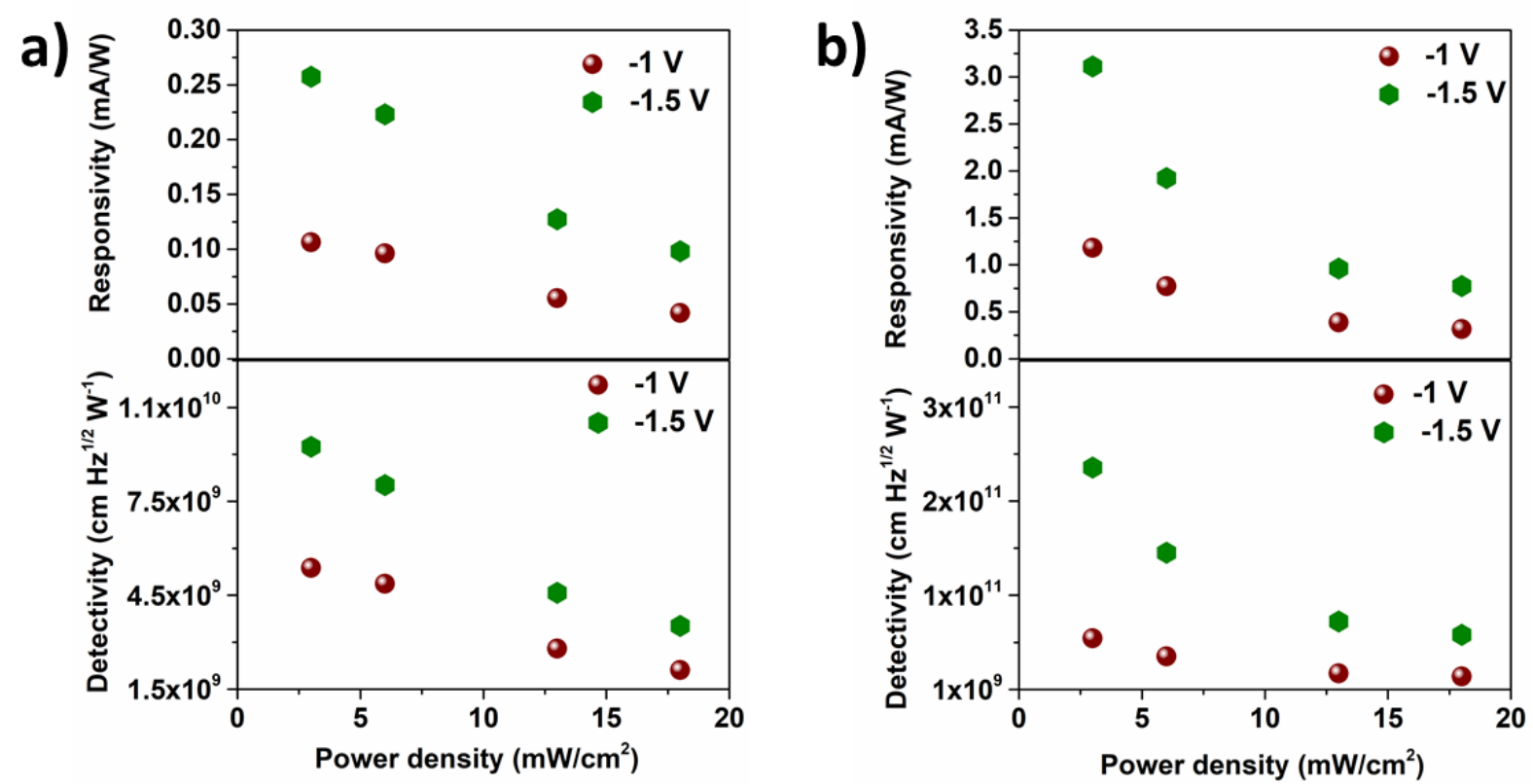

Figure 4. Responsivity and detectivity of the UV photodetectors fabricated with (a) 10 layers of $\mathrm{CuCrO}_{2}$ film, (b) 20 layers of $\mathrm{CuCrO}_{2}$ film for a UV illumination of 3, 6, 13, and $18 \mathrm{~mW} / \mathrm{cm}^{2}$ at an applied bias of $-1 \mathrm{~V}$ and $-1.5 \mathrm{~V}$

The responsivity value was further improved to $1.18 \mathrm{~mA} / \mathrm{W}$ at $-1 \mathrm{~V}$ under $3 \mathrm{~mW} / \mathrm{cm}^{2}$ light intensity by increasing the $\mathrm{CuCrO}_{2}$ film thickness due to the formation of the continuous $\mathrm{CuCrO}_{2}$ film. When the applied bias voltage was increased to $-1.5 \mathrm{~V}$, the responsivity value reached $3.11 \mathrm{~mA} / \mathrm{W}$ under $3 \mathrm{~mW} / \mathrm{cm}^{2}$ light intensity. As mentioned before, the photocurrent value of the detector increased with increasing the light intensity due to the generation of more electron-hole pairs. However, the formation of more electronhole pairs increases the charge carrier scattering and recombination probability which adversely affects the responsivity of the detector. Therefore, the responsivity value of both detectors decreased with increasing light intensity.

Table 1. Photodetector performances of the $\mathrm{p}$-n junction heterojunctions involving $\mathrm{CuCrO}_{2}$ as the p-type

\begin{tabular}{|c|c|c|c|c|c|}
\hline \multicolumn{6}{|c|}{ layer } \\
\hline Materials & $\begin{array}{l}\text { Light } \\
\text { source } \\
(\mathrm{nm})\end{array}$ & $\begin{array}{c}\text { Light } \\
\text { intensity }\end{array}$ & $\begin{array}{l}\text { Responsivity } \\
\text { (mA/W) }\end{array}$ & $\begin{array}{c}\text { Spesific } \\
\text { detectivty } \\
\text { (Jones) }\end{array}$ & References \\
\hline $\mathrm{ZnO} / \mathrm{CuCrO}_{2}$ & 365 & $0.2 \mathrm{~mW} / \mathrm{cm}^{2}$ & $\begin{array}{c}3.43 \text { (zero } \\
\text { bias) }\end{array}$ & $8.5 \times 10^{9}(-1 \mathrm{~V})$ & $\begin{array}{c}\text { (Cossuet et } \\
\text { al., 2018) }\end{array}$ \\
\hline $\mathrm{ZnO}: \mathrm{Al} / \mathrm{CuCrO} 2: \mathrm{Mg}, \mathrm{N}$ & 385 & $\begin{array}{c}0.2-1.2 \\
\mathrm{~mW} / \mathrm{cm}^{2}\end{array}$ & $1.645(1 \mathrm{~V})$ & $3.5 \times 10^{12}(1 \mathrm{~V})$ & $\begin{array}{c}\text { (Ahmadi et } \\
\text { al., 2021) }\end{array}$ \\
\hline $\mathrm{Ga}_{2} \mathrm{O}_{3} / \mathrm{CuCrO}_{2}$ & 365 & $50 \mu \mathrm{W} / \mathrm{cm}^{2}$ & $\begin{array}{c}0.12 \mathrm{~mA} / \mathrm{W} \\
\text { (zero bias) }\end{array}$ & $\begin{array}{c}4.6 \times 10^{11} \\
\text { (zero bias) }\end{array}$ & $\begin{array}{c}\text { (Wu et al., } \\
2021)\end{array}$ \\
\hline $\mathrm{TiO}_{2} / \mathrm{CuCrO}_{2}$ & 365 & $3 \mathrm{~mW} / \mathrm{cm}^{2}$ & $1.18(-1 \mathrm{~V})$ & $\begin{array}{c}5.54 \times 10^{10} \\
(-1 \mathrm{~V})\end{array}$ & In this study \\
\hline $\mathrm{TiO}_{2} / \mathrm{CuCrO}_{2}$ & 365 & $3 \mathrm{~mW} / \mathrm{cm}^{2}$ & $3.11(-1.5 \mathrm{~V})$ & $\begin{array}{c}2.37 \times 10^{11} \\
(-1.5 \mathrm{~V})\end{array}$ & In this study \\
\hline
\end{tabular}


Another crucial parameter for the photodetectors is the detectivty which can be defined as the weak signals detection ability from the noise environment (Deka Boruah, 2019). The specific detectivity values of the detectors were calculated according to the following equation:

$D^{*}=\frac{R}{\sqrt{2 q J_{\text {dark }}}}$

Where $\mathrm{D}^{*}$ is the specific detectivity (typically quoted in Jones, $\mathrm{cm} \cdot \mathrm{Hz}^{1 / 2} / \mathrm{W}$ ), $\mathrm{R}$ is the responsivity $(\mathrm{mA} / \mathrm{W}), \mathrm{q}$ is the elementary charge $\left(1.602 \times 10^{-19} \mathrm{C}\right)$, Jark is the dark current. The specific detectivity values of the photodetectors fabricated with 10 and 20 layers of $\mathrm{CuCrO}_{2}$ are indicated in Fig 4(a) and 4(b), respectively. The specific detectivity value is used to determine the sensitivity of the device. Similar to the responsivity results, the device fabricated with 20 layers of $\mathrm{CuCrO}_{2}$ exhibited maximum specific detectivity of $2.37 \times 10^{11}$ jones at $-1.5 \mathrm{~V}$ under $3 \mathrm{~mW} / \mathrm{cm}^{2}$ light intensity. This result revealed that the device with 20 layers of $\mathrm{CuCrO}_{2}$, which exhibited the highest responsivity, was also more sensitive than the device fabricated with 10 layers of $\mathrm{CuCrO}_{2}$. Comparisons between the device in this work and some reported p-n junction heterojunctions involving $\mathrm{CuCrO}_{2}$ as the p-type layer are listed in Table 1. As can be seen in the Table, various experimental parameters such as light source, light intensity, and bias voltage affect the performance of the device. It is still worth to mention that the photodetector peroformance of the $\mathrm{TiO}_{2} / \mathrm{CuCrO}_{2} \mathrm{p}$-n junction presented in this study is promising and can be further developed to fabricate self-powered $\mathrm{p}-\mathrm{n}$ junction photodetectors.

\section{CONCLUSION}

In summary, the $\mathrm{TiO}_{2} / \mathrm{CuCrO}_{2}$ p-n junction was fabricated on the FTO layer using a simple spin coating method. The $\mathrm{CuCrO}_{2}$ film with two different thicknesses was successfully prepared on the $\mathrm{TiO}_{2}$ layer. The optical absorption of the $\mathrm{TiO}_{2} / \mathrm{CuCrO}_{2}$ samples was strong in the $\mathrm{UV}$ region. On the other hand, the transmission in the visible region decreased with increasing the thickness of the $\mathrm{CuCrO}_{2}$ layer. All the fabricated p-n junction devices behaved like rectifiers, proving the p-n junction formation. Although the formation of the p-n junction, the photocurrent of the device was almost zero under UV illumination in zero bias voltage due to the high defect density at $\mathrm{TiO}_{2} / \mathrm{CuCrO}_{2}$ heterojunction interface. However, the devices generated the photocurrent under the UV light with $365 \mathrm{~nm}$ wavelength when the bias voltage was applied. The device fabricated with 20 layers of $\mathrm{CuCrO}_{2}$ showed higher responsivity and specific detectivity values than the device fabricated with 10 layers of $\mathrm{CuCrO}_{2}$ which can be attributed to the better surface coverage of 20 layers of $\mathrm{CuCrO}_{2}$ on the surface of the $\mathrm{TiO}_{2}$ film. The best performing device with the responsivity of $3.11 \mathrm{~mA} / \mathrm{W}$ and specific detectivity of $2.37 \times 10^{11}$ Jones, at $-1.5 \mathrm{~V}$ under $3 \mathrm{~mW} / \mathrm{cm}^{2}$ light intensity, was fabricated with 20 layers of $\mathrm{CuCrO}_{2}$. The results mentioned above revealed that the delafossite oxides such as $\mathrm{CuCrO}_{2}$ are attractive p-type semiconductors for developing the p-n junction UV photodetectors. Future research directions could include development of the $\mathrm{TiO}_{2} / \mathrm{CuCrO}_{2} \mathrm{p}-\mathrm{n}$ junctions with continous films to obtain self-powered UV photodetectors.

\section{ACKNOWLEDGEMENT}

The author gratefully acknowledges Dr. Hasan AKYILDIZ and Dr. Mustafa KOCABAS for generously providing laboratory facilities to carry out this work.

\section{REFERENCES}

Ahmadi, M., Abrari, M., Ghanaatshoar, M., 2021, "An all-sputtered photovoltaic ultraviolet photodetector based on co-doped $\mathrm{CuCrO}_{2}$ and $\mathrm{Al}$-doped $\mathrm{ZnO}$ heterojunction", Sci Rep, 11, 18694.

Bai, Z., Chen, S.-C., Lin, S.-S., Shi, Q., Lu, Y.-B., Song, S.-M., et al., 2021, "Review in optoelectronic properties of p-type $\mathrm{CuCrO}_{2}$ transparent conductive films", Surfaces and Interfaces, 22, 100824. 
Cossuet, T., Resende, J., Rapenne, L., Chaix-Pluchery, O., Jiménez, C., Renou, G., et al., 2018, "ZnO/CuCrO2 core-shell nanowire heterostructures for self-powered UV photodetectors with fast response", Advanced Functional Materials, 28.

Deka Boruah, B., 2019, "Zinc oxide ultraviolet photodetectors: rapid progress from conventional to selfpowered photodetectors", Nanoscale Advances, 1, 2059-2085.

Dursun, S., Kaya, I. C., Kalem, V., Akyildiz, H., 2018, "UV/visible light active $\mathrm{CuCrO}_{2}$ nanoparticle-SnO 2 nanofiber $\mathrm{p}-\mathrm{n}$ heterostructured photocatalysts for photocatalytic applications", Dalton Transactions, 47, 14662-14678.

Gao, Y., Xu, J., Shi, S., Dong, H., Cheng, Y., Wei, C., et al., 2018, "TiO 2 nanorod arrays based self-powered UV photodetector: heterojunction with $\mathrm{NiO}$ nanoflakes and enhanced UV photoresponse", ACS Applied Materials \& Interfaces, 10, 11269-11279.

Huang, H., Xie, Y., Yang, W., Zhang, F., Cai, J., Wu, Z., 2011, "Low-Dark-Current $\mathrm{TiO}_{2}$ MSM UV Photodetectors With Pt Schottky Contacts", IEEE Electron Device Letters, 32, 530-532.

Karaagac, H., Erdal Aygun, L., Parlak, M., Ghaffari, M., Biyikli, N., Kemal Okyay, A., 2012, "Au/TiOz nanorod-based Schottky-type UV photodetectors", physica status solidi (RRL) - Rapid Research Letters, 6, 442-444.

Kaya, I. C., Akin, S., Akyildiz, H., Sonmezoglu, S., 2018, "Highly efficient tandem photoelectrochemical solar cells using coumarin6 dye-sensitized $\mathrm{CuCrO}_{2}$ delafossite oxide as photocathode", Solar Energy, 169, 196-205.

Kaya, İ. C., Sevindik, M. A., Akyıldız, H., 2016, "Characteristics of Fe- and Mg-doped CuCrO2 nanocrystals prepared by hydrothermal synthesis", Journal of Materials Science: Materials in Electronics, 27, 2404-2411.

Ko, Y. H., Raju, G. S. R., Kim, S., Yu, J. S., 2012, "Diffuse light-scattering properties of nanocracked and porous $\mathrm{MoO}_{3}$ films self-formed by electrodeposition and thermal annealing", physica status solidi (a), 209, 2161-2166.

Li, X., Gao, C., Duan, H., Lu, B., Pan, X., Xie, E., 2012, "Nanocrystalline $\mathrm{TiO}_{2}$ film based photoelectrochemical cell as self-powered UV-photodetector", Nano Energy, 1, 640-645.

Nicolaescu, M., Bandas, C., Orha, C., Şerban, V., Lazău, C., Căprărescu, S., 2021, "Fabrication of a UV photodetector based on $\mathrm{n}-\mathrm{TiO}_{2} / \mathrm{p}-\mathrm{CuMnO}$ heterostructures", Coatings, 11, 1380.

Noman, M. T., Ashraf, M. A., Ali, A., 2019, "Synthesis and applications of nano-TiO2: a review", Environmental Science and Pollution Research, 26, 3262-3291.

Tonooka, K., Kikuchi, N., 2006, "Preparation of transparent $\mathrm{CuCrO} 2: \mathrm{Mg} / \mathrm{ZnO}$ p-n junctions by pulsed laser deposition", Thin Solid Films, 515, 2415-2418.

Wang, H., Yi, G., Zu, X., Jiang, X., Zhang, Z., Luo, H., 2015, "A highly sensitive and self-powered ultraviolet photodetector composed of titanium dioxide nanorods and polyaniline nanowires", Materials Letters, 138, 204-207.

Wu, C., Qiu, L., Li, S., Guo, D., Li, P., Wang, S., et al., 2021, "High sensitive and stable self-powered solarblind photodetector based on solution-processed all inorganic $\mathrm{CuMO}_{2} / \mathrm{Ga}_{2} \mathrm{O}_{3}$ pn heterojunction", Materials Today Physics, 17, 100335.

Wu, J.-M., Kuo, C.-H., 2009, "Ultraviolet photodetectors made from $\mathrm{SnO}_{2}$ nanowires", Thin Solid Films, 517, 3870-3873.

Xie, C., Lu, X.-T., Tong, X.-W., Zhang, Z.-X., Liang, F.-X., Liang, L., et al., 2019, "Recent progress in solarblind deep-ultraviolet photodetectors based on inorganic ultrawide bandgap semiconductors", Advanced Functional Materials, 29.

Xu, J., Zheng, W., Huang, F., 2019, "Gallium oxide solar-blind ultraviolet photodetectors: a review", Journal of Materials Chemistry C, 7, 8753-8770.

Yadav, P. V. K., Ajitha, B., Ahmed, C. M. A., Reddy, Y. A. K., Minnam Reddy, V. R., 2022, "Superior UV photodetector performance of $\mathrm{TiO}_{2}$ films using $\mathrm{Nb}$ doping", Journal of Physics and Chemistry of Solids, 160, 110350. 
Yang, D., Du, F., Ren, Y., Kang, T., Hu, P., Teng, F., et al., 2021, "A high-performance $\mathrm{NiO} / \mathrm{TiO}_{2} \mathrm{UV}$ photodetector: the influence of the NiO layer position", Journal of Materials Chemistry C, 9, 1414614153.

Zhang, N., Sun, J., Gong, H., 2019, "Transparent p-type semiconductors: copper-based oxides and oxychalcogenides", Coatings, 9, 137.

Zheng, L., Teng, F., Zhang, Z., Zhao, B., Fang, X., 2016, "Large scale, highly efficient and self-powered UV photodetectors enabled by all-solid-state $n-\mathrm{TiO}_{2}$ nanowell $/ \mathrm{p}-\mathrm{NiO}$ mesoporous nanosheet heterojunctions", Journal of Materials Chemistry C, 4, 10032-10039.

Zhou, S., Fang, X., Deng, Z., Li, D., Dong, W., Tao, R., et al., 2009, "Room temperature ozone sensing properties of p-type $\mathrm{CuCrO}_{2}$ nanocrystals", Sensors and Actuators B: Chemical, 143, 119-123.

Zou, Y., Zhang, Y., Hu, Y., Gu, H., 2018, "Ultraviolet detectors based on wide bandgap semiconductor nanowire: A review", Sensors (Basel), 18. 